International Journal of Life Sciences
Available online at http://sciencescholar.us/journal/index.php/ijls
Vol. 2 No. 2, August 2018, pages: 51 63
e-ISSN: 2550-6986, p-ISSN: 2550-6994
https://doi.org/10.29332/ijls.v2n2.157

\title{
Flight Behavior, Development of Population and Attack of Stone Leek Leafminer Liriomyza Chinensis Kato (Diptera: Agromyzidae) towards Five Varieties of Onion (Allium cepa L.)
}

\author{
Hamid a, I Wayan Supartha b, I Wayan Susila c, I Putu Sudiarta d \\ Article history: Received 10 March 2018, Accepted in revised form 25 June 2018, Approved 21 July 2018, \\ Available online 7 August 2018
}

\section{Correspondence Author a}

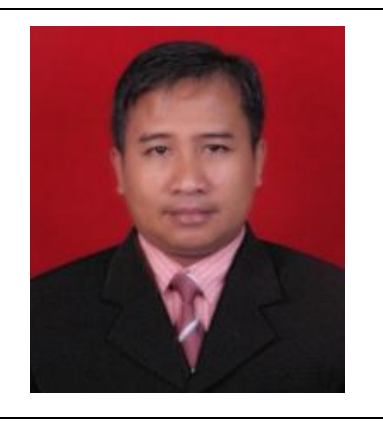

Keywords

Attack Intensity; Attack Percentage;

Flight Behavior;

Liriomyza Chinensis;

Population Development;

\begin{abstract}
Stone leek leafminer Liriomyza Chinensis is an exotic pest that currently has become a major pest in onion plantings in the island of Bali. This study was conducted to determine the behavior of flight, population development and to analyze the level of attack of stone leek leafminer against five varieties of onion (Bima Brebes, Bauji, Tajuk, Probo and Bali Karet). The results showed that adult L. Chinensis has begun to invade the plant since the appearance of leaves of onion plants to the soil surface. The peak of the invasion occurs when the plant is 3 weeks after planting (WAP). While the most adult flight activity occurs at 08.0011.00. The development of the adult population has begun to appear since 1 week and peaked at $3 \mathrm{WAP}$, then decreased to $5 \mathrm{WAP}$ and rose again at $6 \mathrm{WAP}$ then decreased to 8 weeks while the larval population began to monitor 3 WAP and peaked at 5 WAP and then decreased steadily to 8 WAP. The average percentage of stone leek leafminer attack against Bima Brebes varieties (12.91\%), Bauji (9.68\%), Tajuk (10.09\%), Probo (9.96\%) and Bali Karet (13.56\%). Likewise, the average intensity of stone leek leafminer attack against Bima Brebes varieties (19.79\%), Bauji (15.55\%), Tajuk (16.80\%), Probo (17.10\%) and Bali Karet (20.20\%). This shows that the five varieties of onion tested were susceptible to stone leek leafminer, but Bauji varieties tended to be more resistant to it.
\end{abstract}

e-ISSN : 2550-6986, p-ISSN : 2550-6994@ Copyright 2018. The Author. SS Journals Published by Universidad Técnica de Manabí. This is an open-access article under the CC BY-SA 4.0 license

(https://creativecommons.org/licenses/by-sa/4.0/) All rights reserved.

a Doctoral Program (S3) of Agricultural Science, Faculty of Agriculture, Udayana University, Denpasar-Bali, Indonesia

b Integrated Pest Management Laboratory (IPMLab), Faculty of Agriculture, Udayana University, Denpasar-Bali, Indonesia

c Integrated Pest Management Laboratory (IPMLab), Faculty of Agriculture, Udayana University, Denpasar-Bali, Indonesia

d Integrated Pest Management Laboratory (IPMLab), Faculty of Agriculture, Udayana University, Denpasar-Bali, Indonesia 


\section{Contents}

Abstract

51

1. Introduction

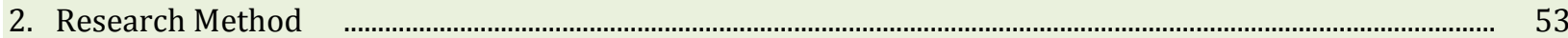

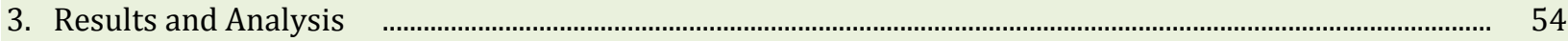

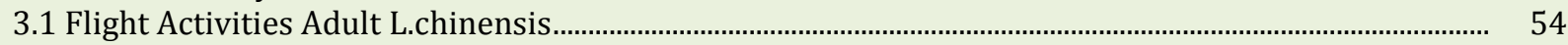

3.2 Development of L.chinensis Population on Onion Plant in Research Sites ............................................. 55

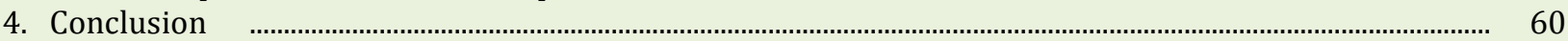

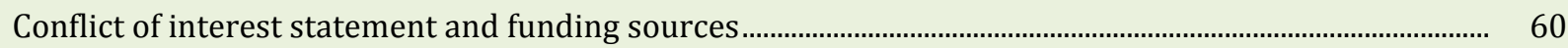

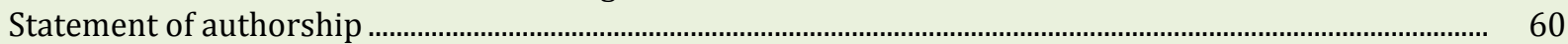

Acknowledgements ～.

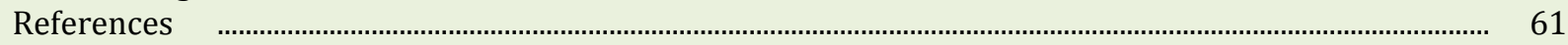

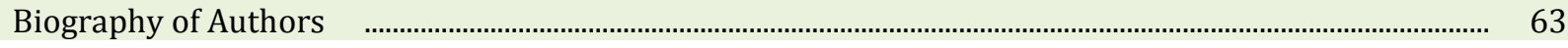

\section{Introduction}

Onion (Allium cepa L.) is a leading commodity that has prospects to be developed. The prospect of onion development is very good in terms of increasing demand in line with the increasing population and the need for onion. Onion production at farm level is still low and fluctuates between 1 and 5 tons/ha (Anwar \& Iriani, 2003). One of the factors causing low productivity of onion in Indonesia is the presence of stone leek leafminer Liriomyza chinensis (Sahabuddin et al., 2012). The pest is a cosmopolitan insect, and in recent years L.chinensis has become an important pest in Allium spp. in several Southeast Asian countries (Tran \& Takagi, 2007), including Indonesia (Rauf et al., 2000). Stone leek leafminer L.chinensis includes monophasic pests that were first found to attack onion in early August 2000 in Indonesia in Klampok village, Brebes district (Central Java) (Rauf \& Shepard, 2001).

The initial symptoms of onion leaves affected by L.chinensis are a white spot caused by a female adult ovipositor puncture when laying its egg. The newly hatched larva goes directly into the leaf cavity and then slices the leaves from within. The direction of the larvae usually starts from the top down to the tubers, and it distinguishes it from other leafminers (Soetiarso, 2007). The larvae can decrease the capacity of plant photosynthesis due to the breakdown of palisade leaf tissue when the larvae make the burrows, even in severe attacks resulting in early leaf decay (Trumble et al., 1985; Supartha, 1998; Baliadi, 2009).

So far the effort of stone leek leafminer pest control by farmers in some areas is generally made by the application of some kind of synthetic insecticides, whose application can reach 2-3 times per week (Baliadi, 2009). Based on the experience of farmers, insecticides used to date have not been able to suppress the pest attacks optimally. The reason for the difficulty of controlling the pest is because the pest size is relatively small so it is difficult to be observed and its existence is only known after the population increases. In addition, the preterm phase of the pest is located within the plant leaf tissue, thus it was protected from contact insecticides (Salvo \& Valladares, 2007), Sibomana, E. (2018). In relation to these problems, another effort is needed to control the pest by tracking the pest bio-ecological information by conducting a series of studies that include: flight behavior and activities, population development and stone leek leafminer L. chinensis attack against several varieties of onion grown by farmers in Bali.

\section{Research Method}

The research was conducted on farmer's land in Bangli village, Tabanan regency, Bali with height $1174 \mathrm{~m}$ above sea level, average temperature between $18^{\circ} \mathrm{C}$ and $25^{\circ} \mathrm{C}$, ordinate $8^{\circ} 18^{\prime} 29^{\prime} \mathrm{EL}$ and $115^{\circ} 9^{\prime} 42^{\prime \prime}$ SL. The study time was conducted from July through October 2017.

Observations of the flight activity of the adult include the flight time in the field, through the installation of adhesive yellow card traps (AYCT) once every eight times i.e. 1, 2, 3, 4, 5, 6, 7 and 8 weeks after planting (WAP). AYCT installed with a height of $15 \mathrm{~cm}$ from the surface of onion plants (Supartha, 1998), Palma, et. al. (2018). AYCT is made from a yellow plastic binder measuring $10 \times 18 \mathrm{~cm}^{2}$ (Chandler, 1985). The number of traps used 
is 15 pieces. AYCT is installed on a bamboo pole with a cord rope made of cotton yarn. Each trap card is smeared with elephant cap trap, on both surfaces. Observation of flight activity of adult L.chinensis with flight time interval at 06.00-07.00, >07.00-08.00, >08.00-09.00, >09.00-10.00, >10.00-11.00, >11.00-12.00, >12.00-13.00, $>13.00-14.00,>14.00-15.00,>15.00-16.00,>16.00-17.00$ and $>17.00-18.00$. The variables observed were the number of adult L.chinensis captured by AYCT.

Observation of adult colonization at the plantation, the observed variables included (1) arrival of adult L.chinensis in onion planting (2) symptoms of female adult ovipositor puncture on plant leaves. Adult initial observation (invasion) in planting was done since 1 WAP with AYCT. Observations for the development of the adult $L$ Chinensis population started from onion crops aged 1 WAP to 8 WAP.

For the purposes of observing L.chinensis attack rate on several varieties of onion plants, which consist of five treatments (varieties of Bima Brebes, Bauji, Tajuk, Probo and Bali Karet). Each treatment was repeated five times so that there were 25 plots of experimental units. For each plot of experimental unit 10 clumps of plants taken as samples were given sequence numbers from 1 to 10. Observation of L.chinensis attack rate against some varieties of onion plants was done every week since onion plants aged 1 WAP to 8 WAP.

Observations of adult L.chinensis flight activity included flight time in the field, through installation. The percentage of crop damage by L.chinensis attack was calculated using the following formula (Moekasan et al., 2004).

$$
P=\frac{a}{a+b} \times 100 \%
$$

Description:

$$
\begin{aligned}
& \mathrm{P}=\text { Percentage of leaf damage }(\%) \\
& \mathrm{a}=\text { Number of affected leaves/plant samples } \\
& \mathrm{b}=\text { Number of healthy leaves/plant samples }
\end{aligned}
$$

To determine the intensity of L.chinensis attacks refers to Herlinda et al. (2005). The intensity of L.chinensis attack was observed directly in the field. Determination of intensity of L.chinensis attack, using the following formula:

$$
I=\frac{\sum(n . v)}{N . Z} \times 100 \%
$$

Description:

$$
\begin{aligned}
& \text { I }=\text { Intensity of attack (\%) } \\
& n=\text { Number of plants having the same scale category of bored leaves } \\
& \mathrm{V}=\text { Value of scale of each attack category } \\
& \mathrm{Z}=\text { The highest scaling value of attack (5) } \\
& \mathrm{N}=\text { Number of plants or parts of plants observed }
\end{aligned}
$$

Score values used to estimate the intensity of the attack on onion plants due to L.chinensis attacks refer to Lologau (2006) combined with criteria according to Mardji (2003), namely:

Table 1

Scale values to estimate the intensity of crop damage caused by L. chinensis attacks

\begin{tabular}{clcl}
\hline $\begin{array}{c}\text { Scale } \\
\text { value }\end{array}$ & \multicolumn{1}{c}{ Number of larval/leaf curve } & Plant damage level (\%) & Plant condition \\
\hline 0 & no symptoms of an attack & 0 & healthy \\
1 & $1-6$ & $>0-20$ & moderately damaged \\
2 & $7-12$ & $>20-40$ & medium damaged \\
3 & $13-18$ & $>40-60$ & heavily damaged \\
\hline
\end{tabular}

Hamid, -, Supartha, I. W., Susila, I. W., \& Sudiarta, I. P. (2018). Flight behavior, development of population and attack of stone leek leafminer liriomyza chinensis kato (diptera: agromyzidae) towards five varieties of onion (allium cepa l.). International Journal of Life Sciences, 2(2), 51-63. https://doi.org/10.29332/ijls.v2n2.157 


\begin{tabular}{llll}
\hline 4 & $19-24$ & $>60-80$ & very heavily damaged \\
5 & $>24$ & $>80-100$ & near-dead plant \\
\hline
\end{tabular}

Data analysis: To know the effect of onion varieties treatment on several variables measured, the data were analyzed using ANOVA. The most significant treatment was tested by Duncan at 5\% (Steel \& Torrie, 1995).

\section{Results and Analysis}

\subsection{Flight Activities Adult L.chinensis}

The observation of the adult L.chinensis flight activity was done by calculating the number of adults trapped in AYCT (Figure 1) between the times at the research site. The number of trapped adults is presented in Table 2.

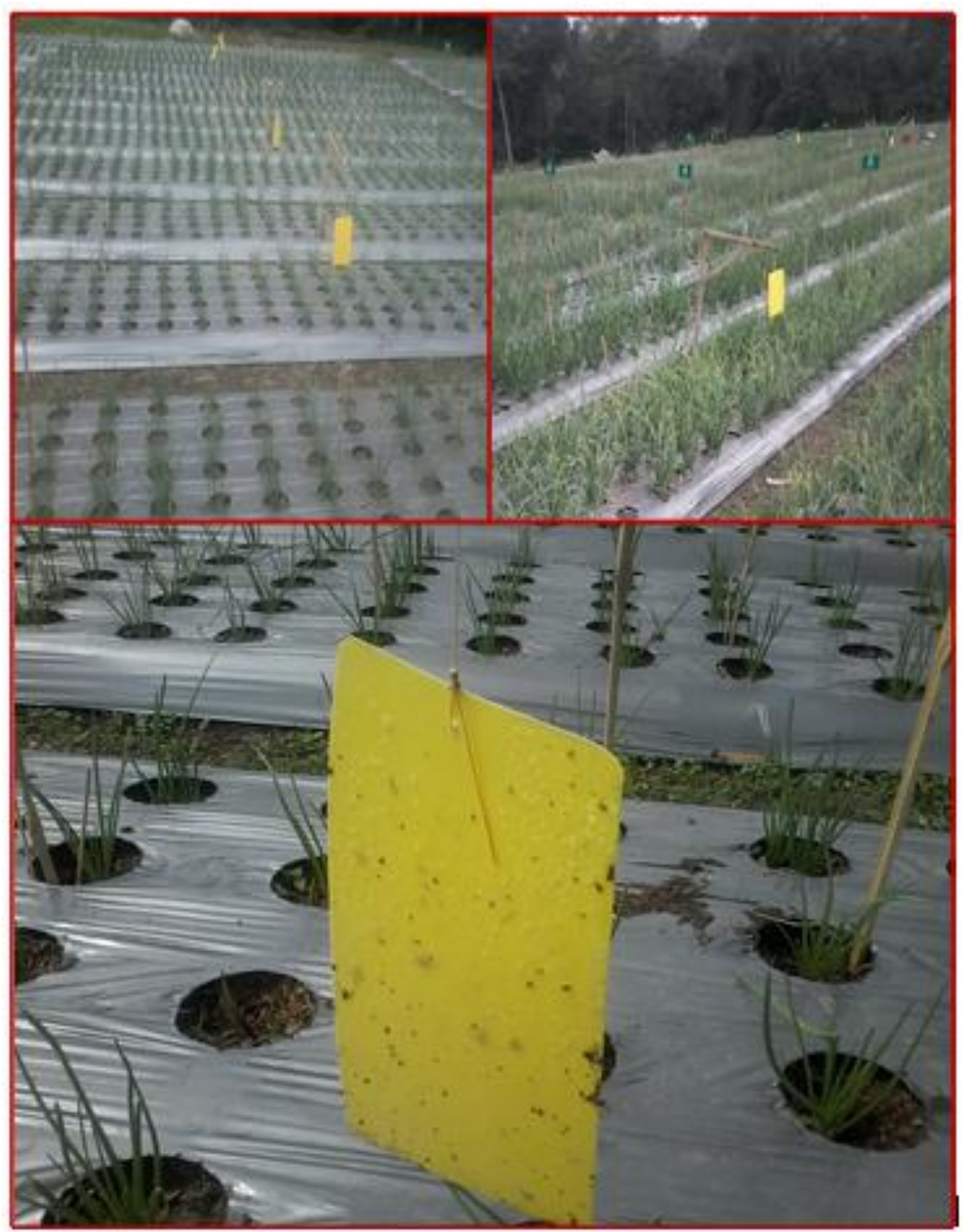

Figure 1. AYCT at the research location 
Table 2

The number of adult L.chinensis trapped by using 15 hourly AYCT on onion plants at the research location

\begin{tabular}{ccccccccc}
\hline $\begin{array}{c}\text { Observation time } \\
\text { (hours) }\end{array}$ & \multicolumn{7}{c}{$\begin{array}{c}\text { Plant age } \\
\text { weeks after planting (WAP) }\end{array}$} \\
\cline { 2 - 9 } & 1 WAP & 2 WAP & 3 WAP & 4 WAP & 5 WAP & 6 WAP & 7 WAP & 8 WAP \\
\hline $06.00-07.00$ & 1 & 8 & 6 & 9 & 4 & 1 & 0 & 1 \\
$>07.00-08.00$ & 2 & 6 & 10 & 6 & 7 & 1 & 4 & 1 \\
$>08.00-09.00$ & 4 & 13 & 23 & 8 & 6 & 4 & 5 & 2 \\
$>09.00-10.00$ & 3 & 14 & 22 & 15 & 6 & 6 & 8 & 3 \\
$>10.00-11.00$ & 4 & 11 & 16 & 13 & 10 & 7 & 5 & 2 \\
$>11.00-12.00$ & 0 & 5 & 15 & 7 & 4 & 4 & 2 & 1 \\
$>12.00-13.00$ & 0 & 3 & 12 & 5 & 7 & 5 & 1 & 0 \\
$>13.00-14.00$ & 1 & 7 & 14 & 12 & 8 & 3 & 2 & 0 \\
$>14.00-15.00$ & 2 & 7 & 9 & 8 & 0 & 4 & 4 & 1 \\
$>15.00-16.00$ & 1 & 9 & 8 & 6 & 3 & 5 & 4 & 2 \\
$>16.00-17.00$ & 1 & 6 & 4 & 6 & 4 & 2 & 0 & 2 \\
$>17.00-18.00$ & 0 & 6 & 7 & 5 & 3 & 1 & 1 & 1 \\
\hline
\end{tabular}

From the data obtained in the field of flight activity of adult L.chinensis most occur between 08.00 and11.00 (Table 2). Adult L.chinensis trapped between 08.00 and 11.00, at plant ages of 1 WAP (57.89\%), 2 WAP (40.00\%), 3 WAP (41.78\%), 4 WAP (36.00\%), 5 WAP (35.48\%), 6 WAP (39.53\%), 7 WAP (50.00\%) and 8 WAP $(43.75 \%)$. This situation indicates that the AYCT catches in the field were strongly influenced by time. This is in accordance with the nature of Liriomyza which is classified as diurnal insects (active during the day) for feeding and mating. This is also supported by Weintraub \& Horowitz (1996) which state that most of the Adult Liriomyza are actively flying after sunrise. The results of observation on the number of adult L.chinensis trapped, using 15 AYCT from 06.00 to 18.00 at plant age of 1 WAP (19 flies), 2 WAP ( 95 flies), 3 WAP (146 flies), 4 WAP (100 flies), 5 WAP ( 62 flies), 6 WAP (43 flies), 7 WAP ( 36 flies) and 8 WAP (16 flies). The high catch at the age of 3 WAP crops was due to the fact that the density of the trapped adult population was also the highest. The results of this study were also supported by the Chavas \& Raman (1987) study which reported that the plant age of 1-6 WAP had a positive correlation with trapped adult L.chinensis.

\subsection{Development of L.chinensis population on onion plant in research location}

Observation of population development of adult L.chinensis through the catch of 15 AYCT traps which was fixed every week is presented in Figure 2. The result of observation indicates that that adult L.chinensis has started to invade since the appearance of leaves of onion plant on the surface of soil, where the number of adult L.chinensis caught at the plant age of 1 week after planting using 15 AYCT of 37 flies (with average catch of 1 AYCT equals to 2.47 flies) and reached its peak at 3rd WAP, that is 632 flies (with average catch of 1 AYCT equals to 42.13 flies). The adult L.chinensis source is thought to be derived from leek plants that were planted around the research site.

The population of larvae in the study sites was monitored from 3 WAP. Observation of 50 onion leaves was made in 3 WAP, and the number of larvae found was 16 . The number of larvae reached its peak at 5 WAP which is 41 flies (Figure 2) while at the time of onion plants aged 6 to 8 WAP, the number of larvae continued to decline, this is because the change of larva stadia into pupa, and adult L.chinensis in the study sites had begun to migrate to other locations.

The linkage between adult arrival and plant life is presumably due to the quantity and quality of food available to adult L.chinensis. This is supported by Rauf (1995) statement that the success of colonization is strongly influenced by the quantity and quality of feed available to support the reproductive potential of the insects. The peak of the adult L.chinensis population trapped by AYCT in the 3rd post-planting cycle was due to pest migration from leek leaves planted around the research site, with a relatively high population at the source of the invasion while the high population of adult L.chinensis trapped AYCT at 6 WAP, was the result of the colonization of these insects.

Hamid, -, Supartha, I. W., Susila, I. W., \& Sudiarta, I. P. (2018). Flight behavior, development of population and attack of stone leek leafminer liriomyza chinensis kato (diptera: agromyzidae) towards five varieties of onion (allium cepa l.). International Journal of Life Sciences, 2(2), 51-63. https://doi.org/10.29332/ijls.v2n2.157 


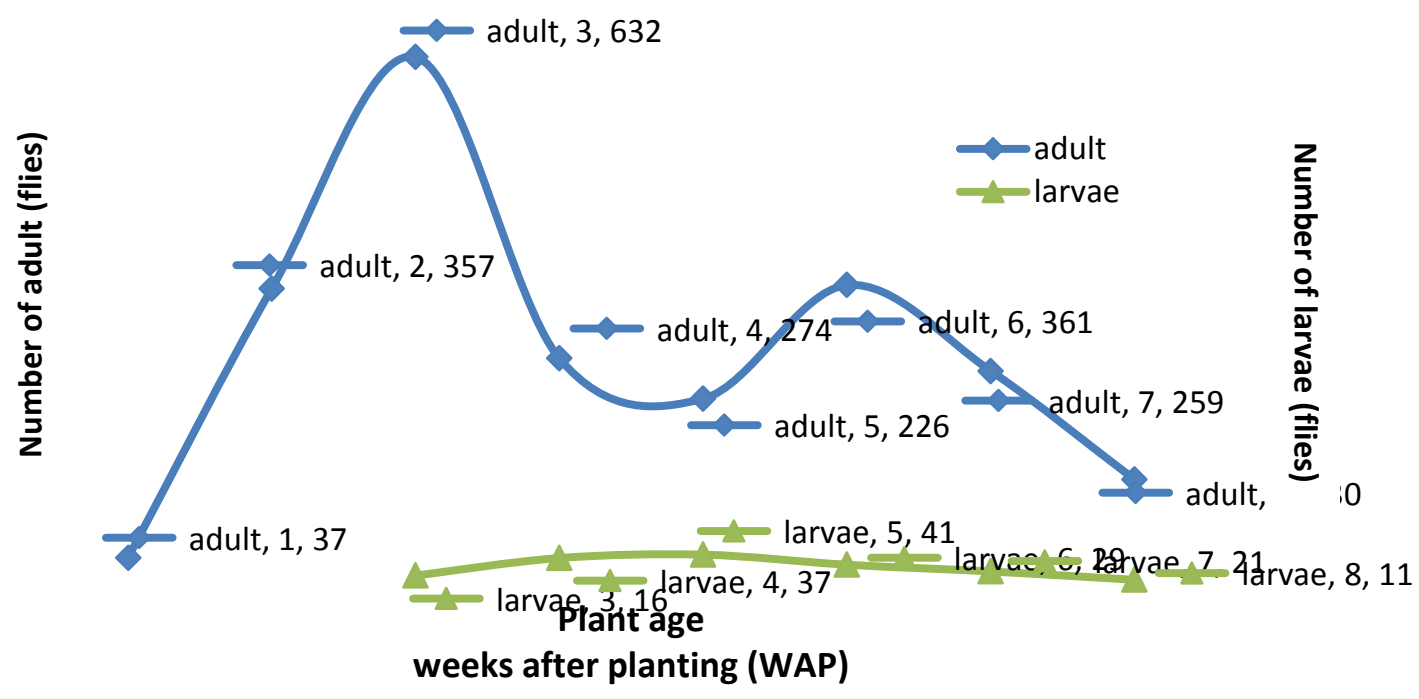

Figure 2. The development of a trapped L.chinensis population using 15 AYCT traps and the number of larvae from 50 leaves of onion plants at the research site

Percentage of L.chinensis Attack on Five Varieties of Onion

Initial symptoms of onion are attacked by L.chinensis, in the form of white spots due to pragmatic ovipositor puncture of the female when laying eggs (Figure 3 section A). Damage to onion crops can be caused by egg laying activities and eat adult L.chinensis and larvae. The form of bored leaves by instar larvae are very difficult to see with the naked eye unless they have dried up. The width and length of the bored leaves will expand as the age of the larva increases. The larval zigzagged bored leaves may appear from the top or bottom of the leaf surface, characterized by the presence of translucent parts (Supartha \& Sasromarsono, 2000) (Figure 3 section B). The larval bored leaves will cause injury to the leaf tissue, and finally, the leaves fall prematurely (Supartha, 1998). 


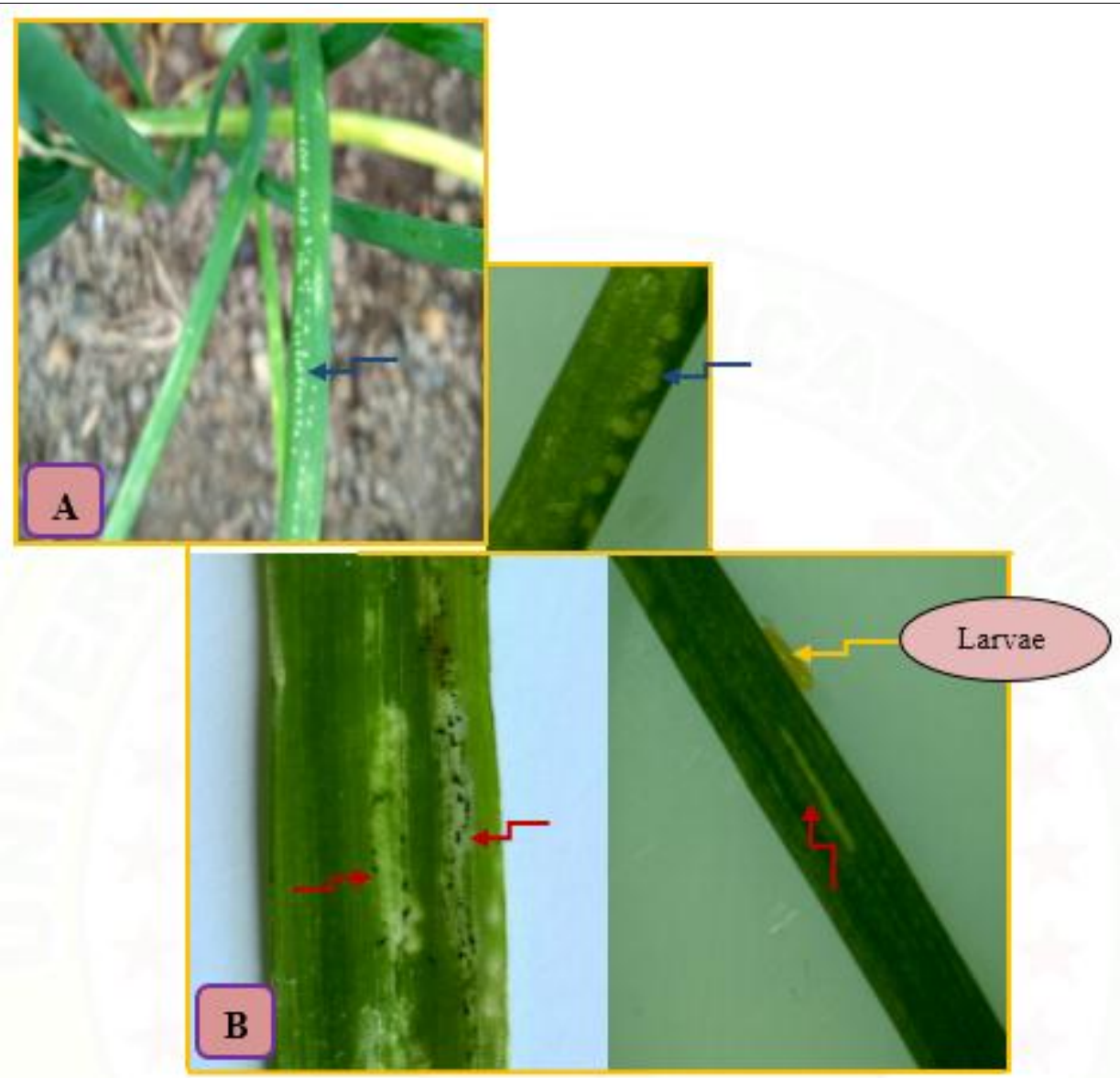

Figure 3. (A) female adult L.chinensis ovipositor puncture (blue arrow) and (B) larval bored leaves of L.chinensis (red arrow) on onion leaves

In severe attacks, almost all of the leaf strands are filled with larval bored leaves, so the leaves become dry and brownish-white as if it was burnt. According to Soetiarso (2007), in addition to attacking the leaves, stone leek leafminer larvae on onion plants can enter up to the tubers and cause the onion tuber to rot, and this is what distinguishes it with other types of leafminers. The larval bored leaves can decrease the capacity of plant photosynthesis due to the breakdown of palisade leaf tissue when the larvae make the burrows, even in severe attacks resulting in early leaf decay (Trumble et al., 1985; Supartha, 1998; Baliadi, 2009).

The results of observation at the research location ranging from 1 WAP to 8 WAP observations, the percentage of stone leek leafminer attack on the five varieties of onion is presented in Table 3 . The average percentage of attacks in 1 WAP was still low (0.16\%) and began to increase in plants aged 2 WAP (1.25\%), 3 WAP (4.64\%) to $27.84 \%$ in 8 WAP onion plants. In general, the percentage of stone leek leafminer attack on Bali Karet varieties was higher and significantly different when the plant was 8 WAP, compared with Bauji and Probo varieties. While the percentage of attacks on the varieties of Bima Brebes and Tajuk did not differ significantly with the varieties of Bali Karet (Table 3). Increased percentage of stone leek leafminer attack on each observation (Figure 4) shows the five varieties were quite susceptible to stone leek leafminer attack.

The results of this study also showed the average percentage of stone leek leafminer attack on Bima Brebes (12.91\%), Bauji (9.68\%), Tajuk (10.09\%), Probo (9.96\%) and Bali Karet (13.56\%). The attack of stone leek leafminer has been seen in the 1 onion crop of WAP, it shows that the adult L.chinensis invasion has occurred since the plant appeared in the soil surface. The high number of stone leek leafminer up to the end of the observation indicates the high population of stone leek leafminer at the research site, so the stone leek leafminer still attacks the plant although the nutritional quality of the plant has decreased especially after the plant entering the tuber formation period.

Hamid, -, Supartha, I. W., Susila, I. W., \& Sudiarta, I. P. (2018). Flight behavior, development of population and attack of stone leek leafminer liriomyza chinensis kato (diptera: agromyzidae) towards five varieties of onion (allium cepa l.). International Journal of Life Sciences, 2(2), 51-63. https://doi.org/10.29332/ijls.v2n2.157 
Table 3

Percentage of L.chinensis attack on five varieties of onion

\begin{tabular}{lllllllll}
\hline \multirow{2}{*}{ Varieties } & \multicolumn{7}{c}{ Observation time weeks after planting (WAP) } \\
\cline { 2 - 9 } & $1 \mathrm{WAP}$ & $2 \mathrm{WAP}$ & $3 \mathrm{WAP}$ & 4 WAP & 5 WAP & 6 WAP & 7 WAP & $8 \mathrm{WAP}$ \\
\hline Bima Brebes & $0,00 \mathrm{a}$ & $1,21 \mathrm{a}$ & $4,16 \mathrm{a}$ & $7,81 \mathrm{a}$ & $16,28 \mathrm{a}$ & $17,04 \mathrm{a}$ & $25,13 \mathrm{a}$ & $31,65 \mathrm{ab}$ \\
Bauji & $0,00 \mathrm{a}$ & $1,45 \mathrm{a}$ & $4,73 \mathrm{a}$ & $6,21 \mathrm{a}$ & $11,59 \mathrm{a}$ & $12,09 \mathrm{a}$ & $17,42 \mathrm{a}$ & $23,93 \mathrm{~b}$ \\
Tajuk & $0,44 \mathrm{a}$ & $1,54 \mathrm{a}$ & $4,97 \mathrm{a}$ & $7,79 \mathrm{a}$ & $10,40 \mathrm{a}$ & $11,31 \mathrm{a}$ & $18,79 \mathrm{a}$ & $25,47 \mathrm{ab}$ \\
Probo & $0,11 \mathrm{a}$ & $0,68 \mathrm{a}$ & $3,82 \mathrm{a}$ & $6,28 \mathrm{a}$ & $11,53 \mathrm{a}$ & $12,88 \mathrm{a}$ & $20,52 \mathrm{a}$ & $23,82 \mathrm{~b}$ \\
Bali Karet & $0,25 \mathrm{a}$ & $1,35 \mathrm{a}$ & $5,53 \mathrm{a}$ & $7,31 \mathrm{a}$ & $15,35 \mathrm{a}$ & $17,16 \mathrm{a}$ & $27,21 \mathrm{a}$ & $34,33 \mathrm{a}$ \\
\hline
\end{tabular}

The numbers followed by the same letter in the same column show no significant difference based on Duncan test of $5 \%$ level.

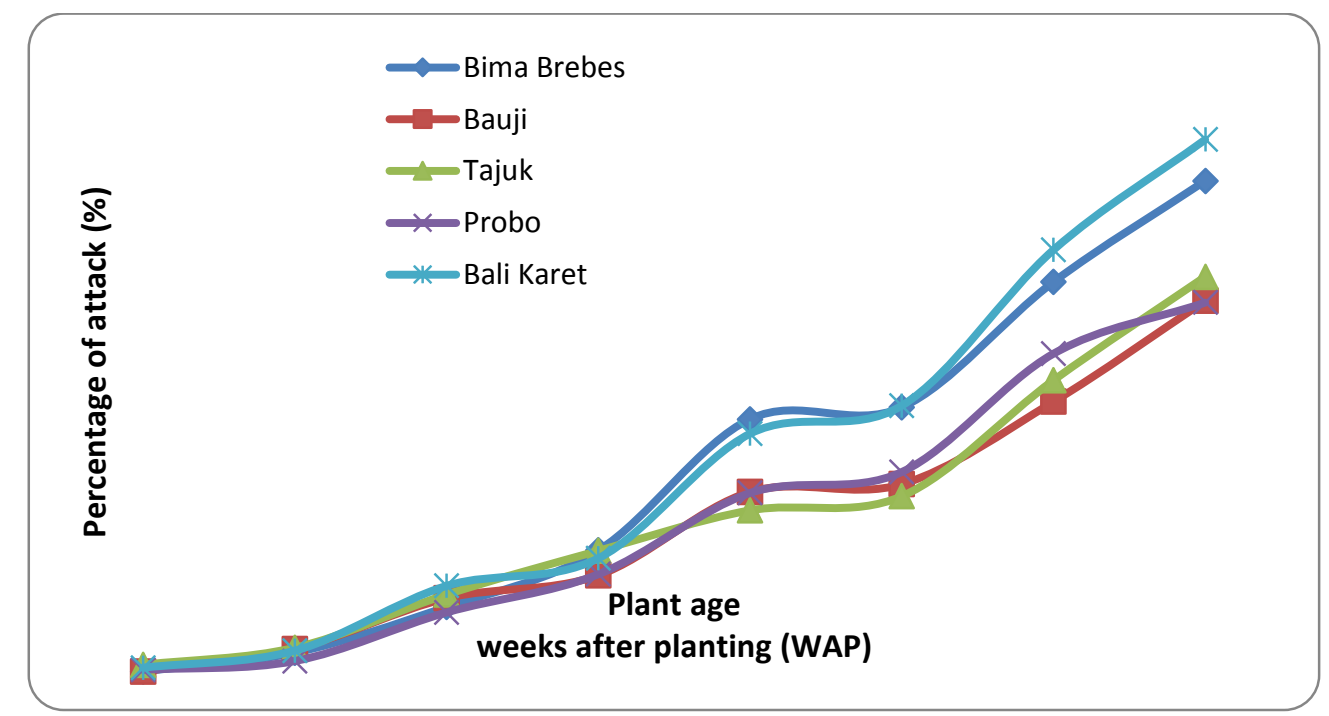

Figure 4. The progression percentage of L.chinensis attacks on five varieties of onion plants

Intensity of L.chinensis attack on five varieties of onion

The intensity of the attack is calculated based on the damage symptoms, either by the female adult ovipositor puncture or by the larval bored of L.chinensis. The results showed that the intensity of the attacks increased every week. The highest intensity of attack occurred in Bali Karet varieties, followed by Bima Brebes, Probo, Tajuk, and the lowest on Bauji (Table 4 and Figure 5). The low intensity of the attack on the Bauji variety is likely due to the compensatory nature of the plant. This suggests that the Bauji variety has a better adaptability when compared to other varieties. One of the underlying properties of plant compensation is the biophysical nature of the plant (Smith, 1989). The results of this study also showed the average intensity of stone leek leafminer attack on Bima Brebes varieties (19.70\%), Bauji (15.55\%), Tajuk (16.80\%), Probo (17.10\%) and Bali Karet (20.20\%). 
Table 4

Intensity of L.chinensis attack on five varieties of onion

\begin{tabular}{lllllllll}
\hline \multirow{2}{*}{ Varieties } & \multicolumn{7}{c}{ Observation time weeks after planting (WAP) } \\
\cline { 2 - 9 } & 1 WAP & 2 WAP & 3 WAP & 4 WAP & 5 WAP & 6 WAP & 7 WAP & 8 WAP \\
\hline Bima Brebes & $0,00 \mathrm{a}$ & $2,80 \mathrm{a}$ & $8,00 \mathrm{a}$ & $15,20 \mathrm{a}$ & $26,80 \mathrm{a}$ & $27,60 \mathrm{a}$ & $35,20 \mathrm{a}$ & $42,00 \mathrm{ab}$ \\
Bauji & $0,00 \mathrm{a}$ & $2,40 \mathrm{a}$ & $8,40 \mathrm{a}$ & $13,20 \mathrm{a}$ & $20,00 \mathrm{a}$ & $20,40 \mathrm{a}$ & $26,40 \mathrm{a}$ & $33,60 \mathrm{~b}$ \\
Tajuk & $0,80 \mathrm{a}$ & $2,80 \mathrm{a}$ & $9,60 \mathrm{a}$ & $15,60 \mathrm{a}$ & $20,80 \mathrm{a}$ & $21,20 \mathrm{a}$ & $28,40 \mathrm{a}$ & $35,20 \mathrm{ab}$ \\
Probo & $0,40 \mathrm{a}$ & $1,60 \mathrm{a}$ & $7,60 \mathrm{a}$ & $14,00 \mathrm{a}$ & $22,80 \mathrm{a}$ & $25,20 \mathrm{a}$ & $30,40 \mathrm{a}$ & $34,80 \mathrm{ab}$ \\
Bali Karet & $0,40 \mathrm{a}$ & $2,80 \mathrm{a}$ & $10,40 \mathrm{a}$ & $14,80 \mathrm{a}$ & $25,20 \mathrm{a}$ & $26,80 \mathrm{a}$ & $36,40 \mathrm{a}$ & $44,80 \mathrm{a}$ \\
\hline
\end{tabular}

The numbers followed by the same letter in the same column show no significant difference based on Duncan test of $5 \%$ level.

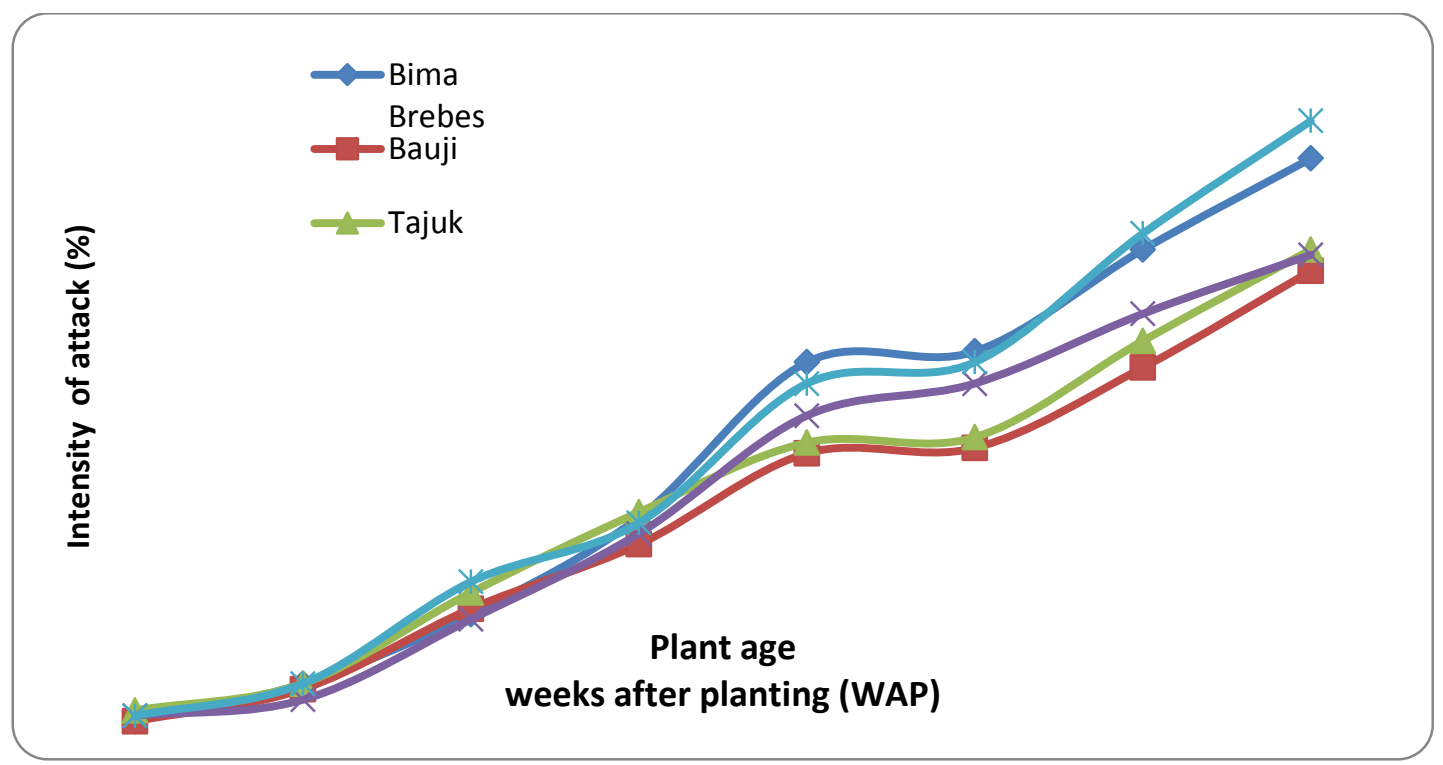

Figure 5. The development of L.chinensis attack intensity on five varieties of onion plants

The existence of different resistance of onion varieties tested in this study is thought to be related to differences in physical factors such as leaf thickness. The results also showed the difference in leaf thickness of the five varieties of onion tested. In the vegetative phase the average thickness of Bauji leaf varieties was not significantly different from the Tajuk varieties, but significantly different from the varieties of Bima Brebes, Probo and Bali Karet while in the generative phase, the average thickness of Bauji varieties of onion was significantly different from the varieties of Bima Brebes, Tajuk, Probo, and Bali Karet (Table 5). It shows that the thickness of plant tissue would affect the insects in the selection process and the determination of the host in egg-laying activities, shelter, and feeding. The high leaf thickness of Bauji varieties is suspected to be disliked by the stone leek leafminer to lay its eggs and also make it more difficult for their eating activities. This is supported by the research of Wei et al. (2000) suggesting that leaf physical structures such as thickness, the thickness of the epidermis and palisade tissue density have a more important role than the density and length of trichomes in inhibiting feeding, female adult oviposition and the development of the Liriomyza larvae.

Table 5

Leaf thickness on five varieties of onion

\begin{tabular}{cccccc}
\hline \multirow{2}{*}{ Plant phase } & Bima Brebes & Bauji & Tajuk & Probo & Bali Karet \\
\hline Vegetative & $0,8785 \mathrm{ab}$ & $0,9324 \mathrm{a}$ & $0,9516 \mathrm{a}$ & $0,6892 \mathrm{c}$ & $0,8245 \mathrm{~b}$ \\
Generative & $2,0332 \mathrm{c}$ & $2,3975 \mathrm{a}$ & $2,0215 \mathrm{c}$ & $2,2137 \mathrm{~b}$ & $2,1484 \mathrm{~b}$ \\
\hline
\end{tabular}

Hamid, -, Supartha, I. W., Susila, I. W., \& Sudiarta, I. P. (2018). Flight behavior, development of population and attack of stone leek leafminer liriomyza chinensis kato (diptera: agromyzidae) towards five varieties of onion (allium cepa l.). International Journal of Life Sciences, 2(2), 51-63. https://doi.org/10.29332/ijls.v2n2.157 
The number followed by the same letter on the line shows no significant difference in the Duncan test of $5 \%$ level.

\section{Conclusion}

a) Adult L.chinensis flight activity mostly occurs between 08.00 and 11.00 . Adult L.chinensis is trapped between 08.00 and 11.00 , at plant age of 1 WAP (57.89\%), 2 WAP $(40.00 \%), 3$ WAP (41.78\%), 4 WAP (36.00\%), 5 WAP (35.48\%), 6 WAP (39.53\%), 7 WAP (50.00\%) and 8 WAP (43.75\%). The catch of AYCT installed at the research site is heavily influenced by time. This is in accordance with the nature of Liriomyza classified as a diurnal insect (active during the day) to find food and mate.

b) Adult L.chinensis has begun to invade since the emergence of leaves of onion plants to the soil surface. Adult L.chinensis trapped by using 15 AYCT traps reached its peak at 3 WAP 632 flies (with an average catch of 1 AYCT is 42.13 flies).

c) Mean of the percentage of stone leek leafminer attack on Bima Brebes (12.91\%), Bauji (9.68\%), Tajuk (10.09\%), Probo (9.96\%) and Bali Karet 13.56\%). Likewise, the average intensity of the attack on stone leek leafminer on Bima Brebes (19.70\%), Bauji (15.55\%), Tajuk (16.80\%), Probo (17.10\%) and Bali Karet (20.20\%). This shows that the five varieties of onion tested are susceptible to stone leek leafminer, but Bauji varieties tend to be more resistant to stone leek leafminer.

Conflict of interest statement and funding sources

The authors declared that they have no competing interest. The study was financed by LPDP.

Statement of authorship

The authors have a responsibility for the conception and design of the study. The authors have approved the final article.

Acknowledgments

The authors wish to express their gratitude to the Indonesia Endowment Fund for Education (LPDP), which has helped finance the research. 


\section{References}

1. Anwar, H. \& Iriani, E. (2003). Technology of Onion Seed Production. Central Agricultural Technology Assessment (BPTP) Central Java. Page 10.

View in (Google Scholar)

2. Baliadi, Y. (2009). Fluctuations Population of Leafminer Liriomyza spp. in Soybean Garden at Kendalpayak Experimental Garden and the Influence of Its Attacks on Soybean Growth. Report of Research Results. Research Institute for Pulses and Tubers, Malang. 19p.

View in (Google Scholar)

3. Chandler, L. D. (1985). Flight activity of Liriomyza trifolii (Diptera: Agromyzidae) in relationship to placement of yellow traps in bell pepper. Journal of economic entomology, 78(4), 825-828.

View in (Google Scholar)

4. Herlinda, S., Rosalina, L. P., Pujiastuti, Y., Sodikin, E., \& Rauf, A. (2012). Populasi dan serangan Liriomyza sativae (Blanchard)(Diptera: Agromyzidae), serta potensi parasitoidnya pada pertanaman ketimun. Jurnal Hama dan Penyakit Tumbuhan Tropika, 5(2), 73-81.

View in (Google Scholar)

5. Lologau, B. A. (2006). Attack Level of Leafminer Liriomyza huidobrensis (Blanchard) and Loss of Results on Potatoes. Agricultural Technology Research Center of South Sulawesi.

View in (Google Scholar)

6. Mardji, D. (2003). Identification and Prevention of Diseases in Forest Crops. Training on Forest Protection Field at PT ITCI Kartika Utama, Samarinda.

View in (Google Scholar)

7. Moekasan, T. K., Suryaningsih, E., Sulastri, I., Gunadi, N., Adiyoga, W., Hendra, A., \& Martono, M. A. (2004). Kelayakan Teknis dan Ekonomis Penerapan Teknologi Pengendalian Hama Terpadu pada Sistem Tanam Tumpanggilir Bawang Merah dan Cabai. Jurnal Hortikultura, 14(3), 188-203.

View in (Google Scholar)

8. Palma, C. A. M., Antonio, V. Ã., \& Torres, L. T. M. O. (2018). A House A Small Company. International Journal of Physical Sciences and Engineering, 2(1), 26-34.

View in (Google Scholar)

9. Muniappan, R., Shepard, B. M., Watson, G. W., Carner, G. R., Rauf, A., Sartiami, D., ... \& Rahman, A. Z. (2009). New records of invasive insects (Hemiptera: Sternorrhyncha) in Southeast Asia and West Africa. Journal of Agricultural and Urban Entomology, 26(4), 167-174.

View in (Google Scholar)

10. Rauf, A., Shepard, B. M., \& Johnson, M. W. (2000). Leafminers in vegetables, ornamental plants and weeds in Indonesia: surveys of host crops, species composition and parasitoids. International Journal of Pest Management, 46(4), 257-266.

View in (Google Scholar)

11. Malipatil, M. B., Ridland, P. M., Rauf, A., Watung, J., \& Kandowangko, D. (2004). New records of Liriomyza Mik (Agromyzidae: Diptera) leafminers from Indonesia. Formosan Entomol, 24, 287-292.

View in (Google Scholar)

12. Salvo, A., \& Valladares, G. R. (2007). Leafminer parasitoids and pest management. Cien. Inv. Agr.(In English) 34 (3): 125-142. Ciencia e Investigación Agraria, 34(3), 125-142.

View in (Google Scholar)

Hamid, -, Supartha, I. W., Susila, I. W., \& Sudiarta, I. P. (2018). Flight behavior, development of population and attack of stone leek leafminer liriomyza chinensis kato (diptera: agromyzidae) towards five varieties of onion (allium cepa l.). International Journal of Life Sciences, 2(2), 51-63. https://doi.org/10.29332/ijls.v2n2.157 
13. Shahabuddin, A. A., \& Gellang, A. (2012). Tingkat serangan dan jenis lalat pengorok daun pada tiga varietas bawang merah di Sulawesi Tengah. J. HPT Tropika, 12(2), 153-161.

View in (Google Scholar)

14. Sibomana, E. (2018). Unpeeling the language policy and planning onion in Rwanda. International Journal of Social Sciences and Humanities, 2(2), 99-114.

View in (Google Scholar)

15. Smith, C. M. (1989). Plant resistance to insects. A fundamental approach. John Wiley and Sons Ltd. View in (Google Scholar)

16. Soetiarso, T. A. (2007, July). Teknologi inovatif bawang merah dan pengembangannya. In Prosiding Seminar Nasional Pengembnagan Inovasi Pertanian Lahan Marginal. Badan Penelitian dan Pengembangan Pertanian. Balai Besar Pengkajian dan Pengembangan Teknnologi Pertanian (pp. 293-324).

View in (Google Scholar)

17. RGD, S. (1995). Torrie JH. Prinsip dan prosedur statistika. Alih bahasa: Sumantri B. Edisi ke-2. Jakarta: Gramedia Pustaka Utama.

View in (Google Scholar)

18. Supartha, I. W. (1998). Bionomics of Liriomyza huidobrensis (Blanchard)(Diptera: Agromyzidae) on potato (Doctoral dissertation, $\mathrm{PhD}$ thesis, Bogor Agricultural University).

View in (Google Scholar)

19. Supartha, I W. \& Sasromarsono, S. (2000). Identification and Symptoms of Attack Liriomyza spp. (Diptera: Agromyzidae) on Potato Plant. Agritrop. Journal of Agricultural Sciences. Denpasar. Udayana University. 19: 5-8.

View in (Google Scholar)

20. Tran, D. H., \& Takagi, M. (2007). Effects of low temperatures on pupal survival of the stone leek leafminer Liriomyza chinensis (Diptera: Agromyzidae). International journal of pest management, 53(3), 253-257.

View in (Google Scholar)

21. Trumble, J. T. (1985). Integrated pest management of Liriomyza trifolii: influence of avermectin, cyromazine, and methomyl on leafminer ecology in celery. Agric. Ecosyst. Environ, 12, 181-188.

View in (Google Scholar)

22. Wei, J., Zou, L., Kuang, R., \& He, L. (2000). Influence of leaf tissue structure on host feeding selection by pea leafminer Liriomyza huidobrensis (Diptera: Agromyzidae). Zoological Studies-Taipei-, 39(4), 295-300.

View in (Google Scholar)

23. Weintraub, P. G., \& Horowitz, A. R. (1996). Spatial and diel activity of the pea leafminer (Diptera: Agromyzidae) in potatoes, Solanum tuberosum. Environmental entomology, 25(4), 722-726.

View in (Google Scholar) 


\section{Biography of Authors}

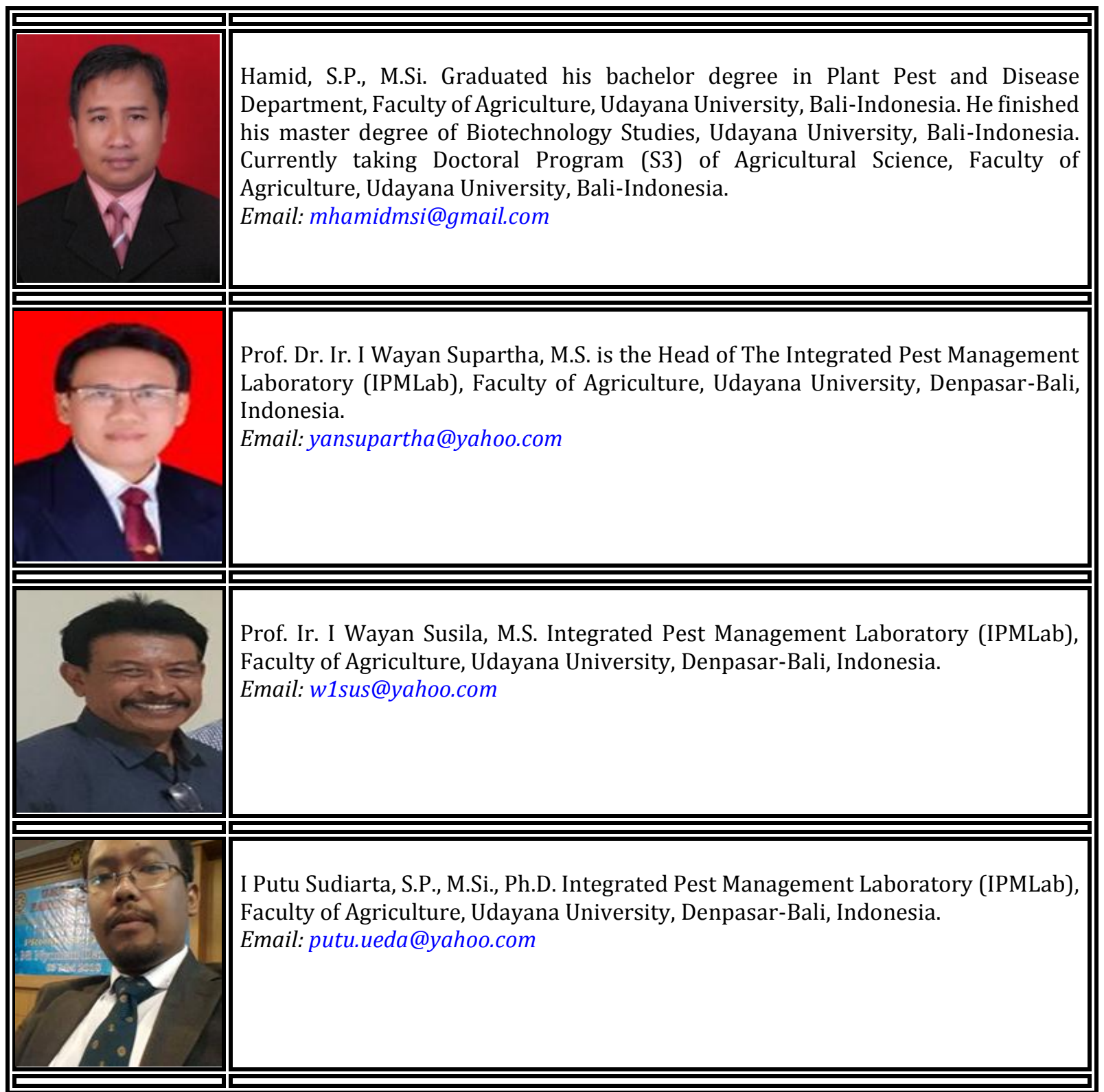

Hamid, -, Supartha, I. W., Susila, I. W., \& Sudiarta, I. P. (2018). Flight behavior, development of population and attack of stone leek leafminer liriomyza chinensis kato (diptera: agromyzidae) towards five varieties of onion (allium cepa l.). International Journal of Life Sciences, 2(2), 51-63. https://doi.org/10.29332/ijls.v2n2.157 